\title{
The Possessive Construction WITH CUID 'PART'
}

\author{
VICTOR BAYDA
}

Irish makes special use of cuid 'part' in the pronominal possessor construction with plural and non-count nouns: e.g. mo chuid eolais 'my knowledge', lit. 'my part of knowledge'. It is argued that cuid is a pseudopartitive marker that explicates the idea of amount of the possessum. ${ }^{1}$

\section{Introduction and data}

Possessivity is understood in a wide sense in this article - as a relation between the referents of two nominals syntactically combined in a prototypically possessive construction. The variety of meanings possessive constructions can have can be demonstrated by the types of predicative possessive constructions identified in Heine (1997: 34ff.):

- Physical possession;

- Temporary possession;

- Permanent possession;

- Inalienable possession;

- Abstract possession;

- Inanimate inalienable possession;

- Inanimate alienable possession.

Possessive constructions can be either predicative (John has a house) or attributive (John's house). For a discussion of predicative and attributive possessive constructions see Seiler (2001). The possessive constructions in question in this paper are of the second kind. Such noun phrases, at least in European languages, usually have the form of a combination of a head-noun denoting the possessum and a dependent noun or a possessive pronoun (or adjective) referring to the possessor. Often a distinction is made between constructions where the possessor is marked by a case form, as in the English so-called 'Saxon genitive' John's house, and those where the possessor is expressed by a prepositional phrase, as in the English so-called 'Norman genitive' the house of John. In Irish the type

\footnotetext{
${ }^{1}$ This research was funded by a grant from the Russian Foundation for Basic Research No 14-06-31247, "The Category of Determination in Irish".
} 
with possessor noun in the genitive is the usual one for expressing attributive possession:
teach Sheáin
house Seán.GEN
'Seán's house'

Various constructions of the second - prepositional - type can be used if the possessum needs to be marked as indefinite, e.g.:

teach de chuid $\begin{aligned} & \text { Sheáin } \\ & \text { house of part } \\ & \text { 'a hoún.GEN }\end{aligned}$
$\begin{aligned} & \text { cara le John's, } \\ & \text { friend Seán with }\end{aligned}$
'a feán

An important restriction on the first type of possessive construction in Irish (the genitive construction) is that here there may be only one definite noun, usually the possessor. The whole phrase is definite even though the possessum is not marked as such. This can be demonstrated by the same phrase, teach Sheáin, where the word for 'house' (teach) is not marked as definite, although it effectively means 'the house of John'.

Another feature of possessive constructions in Irish is that if the possessor is pronominal and the possessum is either a mass or a plural noun, then the word cuid 'part' is included between the pronoun and the noun (this feature is mentioned in section 13.8 in Graiméar Gaeilge na mBráithre Criostai (GGBC), the grammar most often used for general reference):

$\begin{array}{lll}\begin{array}{l}\text { mo chuid } \\ \text { my part }\end{array} & \begin{array}{l}\text { eolais } \\ \text { knowledge.GEN.SG }\end{array} \\ \text { 'my knowledge' } & \\ \text { mo chuid } & \text { leabhar } \\ \text { my part } & \text { book.GEN.PL } \\ \text { 'my books' } & \end{array}$

The present paper is focused on this type of construction. The data comes from two sources: 
- for lexicographic data, Foclóir Gaeilge-Béarla (FGB) was used, the most recent and comprehensive Irish-English dictionary currently available;

- for examples of use of particular linguistic items Nua-Chorpas na hÉireann (NCÉ) was used, an open-access corpus of contemporary Irish (mainly written) which contains 6,264,072 word-uses in the native-speaker part of the corpus, and in which texts are also marked for one of the three major dialects. Sentence-long examples are from NCÉ.

\section{The construction}

The basic meaning of cuid is 'part; share, portion'. In this basic meaning cuid is usually followed by the partitive preposition de, effectively forming a partitive phrase:

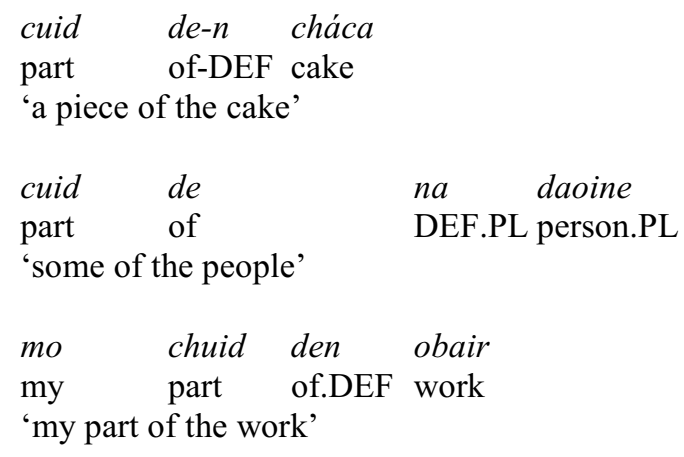

As in other cases of partitive phrases in Irish, a pronominal complement is introduced with $a g$ 'at':

cuid againn
part at.1PL
'some of us'

At the same time cuid may be used in contexts which alter this basic meaning in two ways:

(i) formally - the compliment of cuid is not introduced by de but takes the genitive case;

(ii) semantically - it does not have a partitive meaning, but rather explicates the idea of amount within a possessive construction. 
The construction is used when a non-count or plural noun is modified by a possessive pronoun. In this case cuid comes between the pronoun and the noun:

$\begin{array}{lll}\text { mo } \quad \text { chuid } & \text { eolais } \\ \text { my part } & \text { knowledge.GEN.SG } \\ \text { 'my knowledge' } & \end{array}$

mo chuid leabhar
my part book.GEN.PL
'my books'

The analysis of data from NCÉ suggests that cuid is preferred with most mass nouns, but on a par with a bare pronoun in particular cases (table 1):

Table 1. Mass nouns with bare pronouns $a$ 'his', $a$ 'her', $a$ 'their' and the same pronouns with cuid

\begin{tabular}{|l|l|l|}
\hline & - cuid & + cuid \\
\hline obair 'work' & 5 & 226 \\
\hline caint 'talk' & 87 & 126 \\
\hline gruaig 'hair' & 105 & 110 \\
\hline airgead 'money' & 4 & 84 \\
\hline talamh 'land' & 5 & 60 \\
\hline fuil 'blood' & 0 & 52 \\
\hline am 'time' & 36 & 51 \\
\hline bia 'food' & 7 & 48 \\
\hline scribhneoireacht 'writing' & 6 & 30 \\
\hline eolas 'knowledge' & 11 & 21 \\
\hline
\end{tabular}

Caint 'talk', gruaig 'hair' and am 'time' show quite a high percentage of preference of bare pronouns. In the first two cases this also has a dialectal dimension (table 2):

Table 2. The nouns caint 'talk', gruaig 'hair' with/without cuid

\begin{tabular}{|l|l|l|l|l|}
\hline & & - cuid & + cuid & $p\left(\chi^{2}\right)$ \\
\hline caint 'talk' & Total & 86 & 125 & \\
\cline { 2 - 5 } & Ulster & $\mathbf{3 3}$ & 19 & 0,0522 \\
\cline { 2 - 5 } & Connacht & 22 & $\mathbf{6 1}$ & $<0,05$ \\
\cline { 2 - 5 } & Munster & 31 & 45 & $>0,05$ \\
\hline gruaig 'hair' & Total & 105 & 110 & \\
\cline { 2 - 5 } & Ulster & $\mathbf{2 0}$ & 9 & $<0,05$ \\
\cline { 2 - 5 } & Connacht & 29 & $\mathbf{5 2}$ & $<0,05$ \\
\cline { 2 - 5 } & Munster & 56 & 49 & $>0,05$ \\
\hline
\end{tabular}


It can be seen from Table 2 that Ulster prefers bare pronouns in both cases, and Connacht consistently favours the construction with cuid; in Munster, both options are more or less equally common.

With am 'time' the difference in use with bare pronouns and with the construction with cuid is semantic: in the first case it has the meaning 'time in the past', 'particular period', 'times', whereas in the second it means 'time that one has'.

The same data on plural nouns, however, suggests that the use of cuid with plural nouns is less obligatory than with mass nouns: there are many examples of plural nouns modified by possessive pronouns without cuid.

It should be noted that plural nouns denoting objects coming in pairs (usually inalienable possessions like body parts) are hardly ever used with cuid (table 3):

Table 3. Pair nouns with bare pronoun mo 'my' and pronoun mo with cuid

\begin{tabular}{|l|l|l|}
\hline & - cuid & + cuid \\
\hline súile 'eyes' & 261 & 2 \\
\hline cosa 'feet' & 155 & 0 \\
\hline cluasa 'ears' & 94 & 0 \\
\hline lámha 'hands' & 83 & 0 \\
\hline glúine 'knees' & 54 & 0 \\
\hline tuismitheoir' 'parents' & 48 & 0 \\
\hline bróga 'shoes' & 39 & 1 \\
\hline
\end{tabular}

It should be noted that the zeros in the "+ cuid" section should not be taken as indicating a complete absence of examples: the total number of examples should be taken into account. Lámha, for example, has different numbers if we consider not mo, but $a$ 'his', $a$ 'her', $a$ 'their': 306 "- cuid" against 15 " + cuid". Still, the difference is quite telling.

There are examples (albeit extremely rare), where the possessor is not pronominal but is expressed by a noun and follows the noun referring to the possessum, as in this example from FGB:
cuid
fiona
an
tsagairt
cuid wine.GEN.SG
DEF.M.GEN.SG priest.GEN.SG
'the priest's wine'

NCÉ contains a fair amount of examples where it is used with nominal possessors: 
D' fhéadfainnse a bheith ag broslú chuid fear na hÉireann chun catha 'I could urge the men of Ireland to battle.'

(Séamas Mac Grianna)

Bí ag caint ar chuid iolar na Róimhe nuair a bhí sealán smaicht curtha ar an Eoraip acu.

'Talk of the eagles of Rome when they had the noose of control on Europe.'

(Seosamh Ó Grianna)

Ní raibh a fhios aige cad chuige, ach bhí a chroí ag inse dó gur as cuid fola na bhfear seo a d'fhásfadh ceart agus saoirse na hÉireann.

'He didn't know why, but his heart was telling him that it was from the blood of these men that the right and freedom of Ireland would grow.'

(Seosamh Ó Grianna)

Goidé atá níos lonraí ná cuid réalta na hoíche. Súile máthara.

'What is more luminous than the night stars. A mother's eyes.'

(Dónall Ó Baoill, Stair áitiúil)

Dá rachadh duine ó theach go teach ar maidin lá Bealtaine sul mar néireochadh toit ar an bhaile, bheadh cuid ádh na dtoithe sin leis agus bheadh sé iontach saibhir an bhliain (sin).

'If someone went from house to house on a May Day morning before the smoke rose above the place, he would have the luck of those houses with him and he would be very rich that year.'

(Dónall Ó Baoill, Stair áitiúil)

[N] i raibh cuid fear na hÉireann ina gcodladh ach oiread.

'The men of Ireland were not asleep either.'

(Dónall Ó Baoill, Stair áitiúil)

All these examples come from Ulster which suggests that this is a dialect feature.

This use is perhaps stylistically marked and must be archaic to the contemporary native speaker's ear as informants consulted interpret cuid in such examples as a quantifier over a set of persons or items ('part of', 'some of'), whereas the contexts suggest that it is not 'some of the number or amount' that is denoted by cuid, but rather '(all of) the number or amount': e.g., cuid fear na hÉireann does not mean 'some of the men of Ireland', but 'the men of Ireland'. That these examples should be interpreted this way is clear from examples with an additional quantifier:

[C] huaigh sé anonn le cuid de chuid fear an oileáin.

'He went there with some of the island's men.' 
Here the second cuid cannot refer to a part of fear an oileáin 'men (GEN.PL) of the island', as this meaning is expressed by the first cuid with the partitive preposition $d e$.

Moreover, if such examples denoted partitivity of the NOUN+NOUN.GEN phrase, then the first noun would not be in the genitive, but in the common case with lenition of its initial consonant: e.g., in the example above it would be cuid de chuid fhir an oileáin, because according to the rules governing the forms of nouns in a multiple genitive noun phrase, only the last noun may be in the genitive. In such cases the middle nouns are in the common case and their genitive relation is expressed in a particular way, i.e., by leniting their initial consonants, thus:

[ainmneacha (COM) [fhir (COM) an oileáin (GEN)]]

'the names of the men of the island'

This would entail the above example looking like this:

[cuid $(\mathrm{COM})[$ fhir $(\mathrm{COM})$ an oileáin $(\mathrm{GEN})]]]$

The example, however, has the noun following cuid in the genitive, meaning that an oileáin 'the island (GEN)' is not a dependent of fir 'men' but of cuid fear:

[[cuid (COM) fear (GEN)] an oileáin (GEN)] 'the men of the island'

\section{Semantics}

The semantics of cuid as a full lexical noun is that of a part, so it might be supposed that the function of cuid as a grammatical marker is that of partitivity. At the same time, as we have noted, cuid in the constructions in question does not make use of de with the following compliment, which instead takes the genitive. This means that cuid does not have the same formal function in the possessive constructions as it does in the case of its full lexical use meaning 'part'.

Indeed, there is a difference in Irish between what KoptjevskajaTamm calls partitives ( $a$ cup of that good tea, a pile of Mary's books) and pseudo-partitives ( $a$ cup of tea, a pile of books):

- partitive nominal constructions involve a presupposed set of items referred to by one of the nominals ('that good tea', 'Mary's books'); and the quantifier indicates a subset which is selected from it; 
- in a pseudo-partitive nominal construction the same word merely quantifies over the kind of entity ('tea', 'books') indicated by the other nominal.

(Koptjevskaja-Tamm 2001: 527)

Put simply, the meaning of the partitive construction is that of denoting a PART of something, whereas in the second it is that of an AMOUNT of something. Koptjevskaja-Tamm calls the two components of both constructions Measure and Substance, and she singles out the main difference between the two constructions:

The two constructions differ thus primarily with respect to the referentiality and, in particular, the specificity of their Substance component: in PCs [partitive constructions. $-V B$ ] it receives a specific interpretation, while it is non-specific in PPCs [pseudo-partitive constructions. $-V B]$.

(Koptjevskaja-Tamm 2001: 527)

This can be presented schematically in the following Table 4:

Table 4. Difference between Measure- and Substance-type constructions

\begin{tabular}{|l|l|l|}
\hline & Measure & Substance \\
\hline PARTITIVE & $\begin{array}{l}\text { quantifies over the set of } \\
\text { items }\end{array}$ & set of items, specific \\
\hline $\begin{array}{l}\text { PSEUDO- } \\
\text { PARTITIVE }\end{array}$ & $\begin{array}{l}\text { quantifies over the kind of } \\
\text { entity }\end{array}$ & $\begin{array}{l}\text { kind of entity, non- } \\
\text { specific }\end{array}$ \\
\hline
\end{tabular}

Irish formally distinguishes between these two kinds of constructions. The partitive construction involves the preposition de 'of':

píosa de cháca 'a piece of a cake'

The pseudo-partitive construction is simply constituted by a genitive construction:

píosa cáca 'a piece of cake'

The syntax of cuid in the possessive construction thus resembles that of pseudo-partitive constructions, not that of partitive constructions; this means that cuid functions as an expression of AMOUNT, not PART. 
The use of cuid as a grammatical marker could be said to be bound, as it always appears in a particular context - with possessive pronouns. In nonbound use, cuid has partitive meaning and is used with de.

This brings us to the conclusion that cuid is an expression of AMOUNT that needs specification. Possessivity quantifies over an object by setting apart an AMOUNT of objects of the same type on the basis of their connection to a possessor. The role of cuid is to make explicit the idea of AMOUNT. Therefore, mo chuid leabhar could be rendered as something like 'my amount of books', 'an amount of books that is mine.'

\section{The source of possessive cuid}

We can try to find the source of cuid as a marker of AMOUNT in the pronominal possessive construction.

There are two cases outside the pseudo-partitive possessive construction where cuid is followed by a genitive and not a prepositional phrase with de. In one of them, cuid is qualified by an adjective, usually maith 'good' or mór 'big', yielding 'a good deal of' and 'a lot of' respectively:

cuid mhaith airgid 'a good deal of money'

cuid mhór páipéir, scríbhinni 'a lot of paper, of writings'

Interestingly, cuid mhaith can also be used with de:

cuid mhaith den airgead 'a good deal of the money'

Comparing cuid mhaith with the genitive and with de, one can notice a difference in semantics between PSEUDO-PARTITIVE and PARTITIVE respectively.

The other construction where cuid is followed by a noun in the genitive is the possessive construction with de chuid, as here:

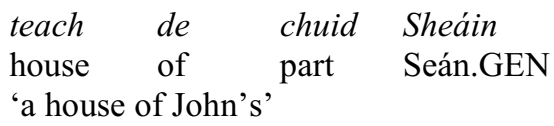

This construction is used when the possessum is non-inclusive. Following Hawkins 1978: 157-67 (see also Lyons 1999: 11), inclusiveness is taken to denote that reference is made to the full set of objects, the full amount of a mass object or the only object. Here cuid certainly does not refer to any sort of 'part' (the gloss only represents the basic lexical meaning of cuid), but more likely to Seán's possessions. Thus, it seems plausible to 
accept that the meaning of cuid here is closer to that of AMOUNT than PART.

If cuid is not followed by a partitive prepositional phrase with de or a genitive, there are no formal ways to access the exact meaning of cuid. However, we can make guesses based on semantic context.

Cuid can function as a collective pronoun referring to a number of people or objects. Cf. examples from FGB:

cuid ag teacht agus cuid ag imeacht 'some coming and others going'

an chuid ghlas 'the green part; the green ones'

Cuid with this function can be used with possessive pronouns:

'Beidh na fatai le fáil amárach, 'deir Tom. 'Abair le Johnny mo chuidse a fhágáil sa stór go tráthnóna, mar beidh mé ag obair.' 'Tá go maith, 'deir Micil, 'agus tabharfaidh mise mo chuid féin duit freisin, mar ní bheidh mise ag bacadh le Earrach i mbliana.

'The potatoes will be available tomorrow,' says Tom. 'Tell Johnny to leave mine (my ones) in the storage till the evening, because I'll be working.' 'All right,' say Micil, 'and I will give you mine own (my own ones) too, because I won't be bothering about spring this year.'

(Micheál Ó Ráighne, Bóithrín na hAille Báine)

'Tá mé ag déanamh gur maith is fiú duit do chuid scaireanna a dhiol anois, a Fhiliméala, tá an-tóir orthu faoi láthair agus b'fhéidir go mbeidh a athrach de scéal ann ar ball. Tá fúm mo chuidse a dhiol go luath, agus dhéanfainnse cúram ded chuidse chomh maith dá mb áil leat é.'

'I understand that you should sell your shares now, Filiméala, they are in demand at the moment and maybe there will be a change to the story soon. I am going to sell mine (my ones) soon and I could take care of yours (your ones) too if you like.'

(Iosold Ní Dheirg, Eachtra Róise)

This resembles the use of cuid in the pseudo-partitive possessive construction as it is combined with possessive pronouns and describes an amount not construed as a part of a whole: in the case of shares it could be argued that there is a limited amount of shares of which shareholders have parts, but in the mentioned context it is more reasonable to understand the number of shares independent of their forming a part of the full set of shares.

These examples, however, are different from pseudo-partitive possessives in that there is no specifier in these cases and cuid here is a 
pronoun. Specification can be done by use of $d e$, but this efficiently changes the meaning of cuid, making it a quantifier:

cuid de na fir 'some of the men'

There are other uses of cuid that provide evidence of semantic development from 'part' to 'amount'. verb:

Cuid mhaith 'a good deal' can be used as an adverb modifying a

áit a gcloionn sé cuid mhaith le bunleagan an tsoiscéil 'where he adheres quite much to the basic version in the Gospel'

chuaigh siad suas cuid mhaith thar na mblianta 'they [the numbers] went up quite a lot over the years'

It is obvious that the verb-modifying adverbial use of cuid mhaith stems from the noun-modifying adverbial use, and it makes sense to assume that this is based on an AMOUNT meaning and not a PART meaning as has been shown above.

There are also more lexicalized uses of cuid:

(a) one's own

do chuid a bhaint as rud 'to take one's share of sth.; to make sth. suffice for one's needs'

(b) means of subsistence

ár gcuid a shaothrú 'to earn our bread, our living'

do chuid a chaitheamh 'to spend one's substance'

bheith beo ar chuid na muintire eile 'to live at other people's expense'

(c) food, meals

do chuid a dhéanamh 'to take one's meal(s), to eat'

a chuid a thabhairt do dhuine 'to give s.o. his meal(s), to feed s.o.'

It seems reasonable to suggest that these meanings have evolved on the base of the meaning of AMOUNT rather than PART, not in the direction of more abstract grammatical units, but of lexical ones.

To sum up - there are cases of cuid modified by an adjective maith or mór, where cuid may be used in a partitive as well as pseudo-partitive construction. This is the only case where it can be used pseudo-partitively outside the pronominal possessive construction. The construction with de chuid is also more likely to be an instance of the use of cuid to express the 
meaning of AMOUNT, rather than PART, since cuid here describes "what belongs to someone or something". In the case of lexicalised uses of cuid, where it has its own referent and there is no case for a pseudo-partitive construction, what is important is that cuid is a lexicalized version not of the meaning of PART, but that of AMOUNT.

It is difficult to make a definite claim as to whether one of these uses formed the base of the use of cuid in pronominal possessives. It is more likely that all these uses, including the use in pronominal possessives, are developments of a potential of cuid to denote AMOUNT, rather than PART.

\section{Conclusion}

The cuid possessive construction forms a pseudo-partitive construction with the noun denoting the possessum which is either a mass or a plural noun. The use of cuid with mass nouns is highly preferred, whereas with plurals less so. The construction is not used with singular nouns or those denoting possessions coming in pairs as in these cases there is no AMOUNT in question, the number of persons or items is given by definition. The construction is also used with nominal possessors, though this use is very uncommon and seems to be a feature of the northern dialects.

The pseudo-partitive nature of the construction means that cuid expresses the idea of the AMOUNT of the possessum which is nonspecific, quantifying over a type of objects, unlike partitive constructions which quantify over a set.

It is difficult to find a source of the construction among other uses of cuid, as they are quite disparate; rather, at the basis of its use in the possessive construction lies the general potential of cuid to express AMOUNT, which is also manifested in several other uses of cuid.

Lomonosov Moscow State University

\section{Abbreviations}

FGB - Ó Dónaill, N., ed., 1977, Foclóir Gaeilge-Béarla [Irish-English Dictionary], Baile Átha Cliath: An Gúm.

GGBC - Graiméar Gaeilge na mBráithre Críostai [Christian Brothers' Irish Grammar], 1960, Baile Átha Cliath: An Gúm.

NCÉ - Nua-Chorpas na hÉireann [The New Corpus for Ireland], www.corpas.focloir.ie [accessed 20.06.2016]. 


\section{References}

Heine, B., 1997, Possession: Cognitive Sources, Forces, and Grammaticalization, Cambridge: Cambridge University Press.

Hawkins, J. A., 1978, Definiteness and Indefiniteness: A Study in Reference and Grammaticality Prediction, London: Croom Helm.

Koptjevskaja-Tamm, M., 2001, 'A piece of the cake' and 'a cup of tea': Partitive and Pseudo-partitive Nominal Constructions in the CircumBaltic Languages', in Dahl, Ö., \& Koptjevskaja-Tamm, M., eds., CircumBaltic Languages. Volume 2: Grammar and Typology (Studies in Language Companion Series, 55). Amsterdam/Philadelphia: John Benjamins Publishing Company, 523-68.

Lyons, C., 1999, Definiteness, Cambridge: Cambridge University Press. Seiler, H., 2001, 'The Operational Basis of Possession. A Dimensional Approach Revisited', in Baron, I., Herslund, M., \& Sørensen, F., eds., Dimensions of Possession (Typological Studies in Language, 47). Amsterdam/Philadelphia: John Benjamins Publishing Company, 27-40. 